\title{
Evaluation of Externalities Associated with Rare Earth Exploitation at Bayan Obo
}

\author{
Baolu Zhou, Zhongxue Li and Yiqing Zhao* \\ Department of Mineral Resources Engineering, University of Science and Technology Beijing, Beijing, China
}

\begin{abstract}
Rare earth elements (REEs) are a kind of new materials which have excellent optical, electrical and magnetic properties, and they play an important role in the development of high technology and green energy industries. With abundant reserves and a wide range of REE type, rare earth industry has a rapid development in China in recent years. However, environmental issues associated with REE exploitation have severely restricted the sustainable development of rare earth industry in China.

At present, literatures on the externalities of REE exploitation are very limited, especially in China. This paper builds an evaluation model based on life cycle evaluation to estimate the external costs of REE exploitation at Bayan Obo. The results show that the external costs for producing one metric tonne of rare earth oxides (REO) in Bayan Obo was CNY 34739 in 2013, the external costs of waste gas, waste water, radioactive substance, REE resource depletion, and land occupation are CNY $14945,12515,1400,3199$, and 2680, respectively. Waste gas and water constitute about $79 \%$ of the total external costs. The internalization of the external costs would reduce the financial profit of Northern Rare Earth (Group) by $18 \%$. This study has taken into account only those externalities whose market values can be estimated, and therefore the external costs of REE exploitation in Bayan Obo is likely to be underestimated. The results fill the gap in literature and provide further understanding on the external cost of REE exploitation.
\end{abstract}

Keywords: rare earth element, external cost, life cycle assessment, Bayan Obo

\section{Introduction / Background}

Along with increasing concern about environmental pollution problems caused by the usage of fossil fuel and the shortage of fossil energy, a transition has occurred where development has moved toward green and renewable energy sources with less pollutant emissions (Stegen 2015). Rare earth elements (REE) are a group of important raw materials for these trends since they have unique magnetic, electronic and optical properties, and thus make them widely used in making highperformance magnets and energy saving lamps (U.S. DOE 2010). In addition, REE are crucial for manufacturing of widespread high-tech applications in medical, defense and electronic industries. Many countries have made mediumterm and long-term plans for the development of their REE industries, and the annual growth rate of global REE demand is expected to increase by $6 \%$ by 2020 , and reach about 170,000 metric tons of rare earth oxides (REO) by 2020 (Rollat et al 2016).

REE consist of 17 elements including 15 lanthanide elements (atomic number 57-71), plus yttrium (Y) and scandium $(\mathrm{Sc}), \mathrm{Y}$ and $\mathrm{Sc}$ are considered as REE since they have similar properties with other REEs. Generally, REE are divided into two groups: light rare earth elements (LREEs) (atomic number 57-64), and heavy rare earth elements (HREEs) (atomic number 65-71, plus Sc and Y). Although named "rare", REEs are not actually rare in geological occurrence, REE cerium is more abundance than some common industrial elements like copper and lead, and 11 out of the 17 REEs are more common than Tin in the Earth's crust. There are currently about 200 known REE-bearing minerals widely distributed in the world, mostly represent as carbonatites. However, REE are rare to find in economically viable deposits. REE extraction in industrial scale currently is mainly from 4 minerals, namely bastnaesite, monazite, xenotime, and ion-absorption clay (Kanazawa and Kamitani 2006), about $90 \%$ of world REE reserves represents in bastnaesite, the second is monazite, xenotime is a marginal source of REEs, and ion-absorption clay currently is only founded in southern China. The major potential countries are China, Brazil, Australia, United States, and India. Bayan Obo in China and Mountain Pass in the United States are the world's first and second-biggest deposits containing REEs respectively.

In recent years, many new REE projects are underway all over the world, such as Bear Lodge in the United States, Nolans Bore in Australia, Strange Lake in Canada, Kvanefjeld in Greenland, and the world output of REE is increasing since 2011. At present, world REE production mainly comes from China and Australia. Australia is responsible for $8 \%$ of global REE production, China represents about $85 \%$ (USGS 2016). The production of REEs in China is mainly concentrated in six REE enterprises, and Northern Rare Earth (Group) accounts for about 50\% of the total national production, Bayan Obo mine situated in Inner Mongolia China is its production mine.

There are many environmental issues associated with the production and extraction of REE. Apart from the

* Corresponding Author: Y.Q. Zhao, zyq@ustb.edu.cn, phone: +86 18500225299

Copyright @ 2017 Canamaple Academia Services, http://press.camdemia.ca

DOI: 10.15273/gree.2017.02.007 
consumption of coal, electricity, and gasoline, a large amount of chemical reagent is required in the extraction and separation of REE, as similar physical and chemical structure of 17 REEs make it difficult to separate them from each other. Therefore, a great deal of pollutants which can be toxic with potential damage to the ecological environment and human health are generated in the process of REE separation, such as carbon dioxide and sulfur dioxide from coal and oil burning, fluoride from calcination, and ammonia-nitrogen wastewater from extraction process. Furthermore, nearly all REE ores are accompanied with radioactive elements (e.g. thorium, uranium). Natural thorium usually consists of the isotope ${ }^{232} \mathrm{Th}$ with a half-life of 14.05 billion years, and its disposal can be very expensive, besides, there are currently no large industrial scale application of thorium. If directly into environment without proper treatment, the radioactive waste can cause serious pollution to surrounding environment. Thus, disposal of radioactive REE ores has become an important problem facing the REE producers (Binnemans and Jones 2015).

Bayan Obo Fe-REE-Nb deposit, located in $135 \mathrm{~km}$ northern of Baotou, is the largest REE deposit in China. Since the 1980s, its total output of REEs accounts for about $53 \%$ of the national total output ( $\mathrm{Su} 2009$ ). The operation revenue of China Northern Rare Earth constitutes of $1.73 \%$ of Baotou GDP in 2015 and the operation revenue of REE minerals constitutes of about $68.3 \%$ of the total operation revenue. However, environmental issues associated with REE production is obsessing local governments, the pollution discharge of Northern Rare Earth is usually not up to the national profession standard, waste water and tailing reservoirs could lead water quality deterioration, the local residents' health is also serious affected, several villages surround tailing have moved away, and it therefore has become one of the most important incentives for China making REE policy (Wübbeke 2013). Local governments also have to balance rare earth industrial development and environmental protection. However, governments usually fail to make effective trade-off since lack of information about the external costs of REE exploitation. This paper aims to estimate the external costs of REE production in Bayan Obo, provide valuable information for local authorities and researchers to draft policies for the sustainable exploitation of REE in China.

\section{Framework for Assessing the Externalities of Rare Earth Production in Bayan Obo}

There have been many reports and literatures on the environmental issues associated with REE production. However, most of these studies only qualitatively describe those environmental problems, literatures quantitatively analyzed the external costs incurred by these problems are very limited. To date the most widely used methodology for evaluating the environmental performance of a process is the life cycle assessment (LCA), which take all energy and resources consumption and pollutant emissions into consideration along with all life cycle stages: from the extraction of raw materials to end of life treatment (Zaimes et al 2015). Since the early 1990s, the LCA methodologies have been developed. Therefore, there are currently many LCA standards, such as CML 2001, Impact 2002+, EcoIndicator 99, and International Reference Life Cycle Data System (ILCD) recommendation. According to the ILCD recommendation, the purpose of life cycle impact assessment can be measured in terms of indicators for the Areas of Protection, which can be classified as three parts: human health, natural environment, and natural resources (EC JRC 2010).

Impacts on human health caused by various type of environmental stressors may lead to mortality and morbidity, the negative effects on natural environment as a consequence of exposure to waste gas, water, and other harmful contaminants may lead to potentially disappeared fraction of species. However, a clear distinction between the human health and natural environment does not exist, and they are intrinsically linked. The removal of natural resources from environment which results in a decrease in the availability of the total resource stock, and it also generate an external impact, as non-renewable resources are finite and renewable resources require time to regenerate. The LCA can be considered from above three aspects.

In the production of REEs, a large amount of energy and resources (e.g. coal, electricity and oil) is consumed in the process of calcination and smelting, as a result, a great deal of waste gas, waste residue and waste water is discharged, which could cause great damage to local ecological environment, in turn result in decline in environmental quality. Along with environmental deterioration, the natural environment and human health are severely affected. The emission of carbon dioxide and sulfur dioxide will contribute to global warming and acidification. Heavy metals, nitrogen and phosphorus in waste water could cause water eutrophication, soil contamination and heavy metal pollution. All of these could result in abnormal climate such as acid rain, sea level's up, droughts, crop yield decrease, and increase rates of respiratory and digestive disease linked to air and water pollution. At the same time, the exploitation of rare earth ores has to take up much of the land resources, which will affect the original ecosystem functioning and significant disruption of ecosystems can result in life sustaining ecosystem goods and services. The consumption of REE resources also affect the benefit of human well-being of future generation, therefore, compensation for REE resource consumption is necessary.

In this study, we build a framework of five cost categories to assess the total external costs of REE exploitation in Bayan Obo: (1) the damage of waste gas; (2) the damage of waste water; (3) the damage of radioactive substance; (4) the damage of REE resources depletion; and (5) the damage of land occupation. We calculate the external cost of every category by using the methods of environmental economy such as human capital method, productivity changing method, and so on from three aspects: natural environment, human health, and natural resources, and we only estimate those externalities which give rise to financial costs. 
This framework not include the external costs incurred by the producer themselves e.g. monitoring costs and the administration costs incurred by government authorities and agencies for assessing environmental and health parameters, and the positive external costs has not measured in this framework. However, we estimated the positive external costs through assessing the operation revenue associated with REE producers and the market value of REE products.

\section{External Cost Assessment on REE Exploitation 3.1 Damage to nature capital - waste gas}

REO production contributes to atmospheric pollution mainly through the emissions of four gases: carbon dioxide, sulfur dioxide and nitrogen oxides from energy/fossil fuel consumption and smelting process, and waste gas containing fluoride and heavy metals from smelting process. According to the yearbook of nonferrous metals industry of China (China Nonferrous Metals Industry Association 2014), industrial pollutant generation and discharging coefficient handbook and the calculation of REO production chemical formula based on typical technological processing, production of 1 ton of REO in Bayan Obo emits $15390.5 \mathrm{~kg}$ carbon dioxide, $949.43 \mathrm{~kg}$ sulfur dioxide, $467.33 \mathrm{~kg}$ nitrogen oxides, $7.34 \mathrm{~kg}$ carbon monoxide, and $297.2 \mathrm{~kg}$ hydrogen fluoride in 2013. These substances in turn contributes to global warming $\left(\mathrm{CO}_{2}\right)$ and acidification $\left(\mathrm{SO}_{2}\right.$, nitrogen oxides, hydrogen fluoride). Global warming could lead serious consequences (e.g. sea level rising, incidence of some diseases rising, and the food chain disruption), acidification also could give rise to fatal results (e.g. acid rain, acid fog, and soil acidification).

Extensive research is underway on the external costs of these gases, which are presently, however, full of controversy, as it's hard to estimate the external costs of natural environment change resulting from global warming and acidification. The natural environment has suffered pollution only when waste gas exceeds the threshold value of natural self-purification, even exceed the threshold value, the damage also varied with the pollutant concentration, the relation between the natural environment damage and the waste gas concentration is not simply linear. In fact, according to the environmental monitoring results, there is no acid rain in Baotou in 2013. So, in this study, we mainly calculate the human health costs incurred by global warming and acidification. For other waste gases, they can be calculated relative to the $\mathrm{CO}_{2}$ and $\mathrm{SO}_{2}$ based on classification factors for global warming and acidification. The external costs of carbon dioxide and sulfur dioxide have been calculated by the life cycle inventory and willingness-topay(WTP) methods (Li et al 2013), and indicating an external cost of CNY 0.047 per metric ton carbon dioxide and CNY 9.84 per $\mathrm{kg}$ sulfur dioxide in Baotou in 2013 based on Li's literature ( $\mathrm{Li}$ et al 2013). These studies indicate that the external costs of production of one metric ton of REO in Bayan Obo in 2013 are CNY 0.727 for carbon dioxide, and CNY 14944 for sulfur dioxide, the total external cost of gases is CNY 14945.

\subsection{Damage to nature capital - waste water}

Nitrogen, phosphorus, heavy metals (mercury, lead, arsenic, cadmium), and fluoride emission from REO production can pollute ground and surface water, disrupt water ecosystem, bring about eutrophication and toxicity on aquatic organisms, in turn result in the reduction of tourist spot and the tourists, increase the incidence of disease of digestive tract (acute chordapsus, bacillary dysentery) and virus hepatitis in population drinking contaminated water ( $\mathrm{Li} 2012$ ), and increase the water cost of industry and agriculture, and the cost of sewage treatment. However, when contaminated water has not yet caused degradation of water quality, the external costs is negligible. Along with degradation of water quality caused by waste water, the external cost will be increase, and there exists a threshold between water quality and external cost, the external cost of water quality on each area is list as equation (1) ( $\mathrm{Li}$ and $\mathrm{Su} 2003$ ), where $\mathrm{Li}, \mathrm{Ki}$, and $\mathrm{Q}$ are, respectively, the ratio of the external cost to the total production value of specific area, affecting parameters, and the water quality.

$$
\mathrm{L}_{\mathrm{i}}=\mathrm{K}_{\mathrm{i}}\left(\frac{\mathrm{e}^{0.54(\mathrm{Q}-4)}-1}{\mathrm{e}^{0.54(\mathrm{Q}-4)}+1}+0.5\right)
$$

Baotou is highly dependent on groundwater resources. Base on the calculation method of $\mathrm{Li}$ ( $\mathrm{Li}$ and $\mathrm{Su} 2003$ ), the quality Q for groundwater in Baotou is estimating 3.973 based on environment bulletin of 2013; affecting parameters $\mathrm{K}$ for crop farming, animal husbandry, fishery, and tourism respectively, are $0.4,0.2,1$, and $0.106 ; \mathrm{K}$ for industry has been calculated by Lu and Ling (2010) is 0.014; the treatment cost of industrial water per ton is CNY 0.2 higher than the life water; the waste water also affect human health, the incidence of chordapsus, bacillary dysentery, viral hepatitis, and liver cancer respectively, are $6.764 \times 10^{-4}, 2.145 \times 10^{-4}, 6.936 \times 10^{-4}$, $3 \times 10^{-4}$, based on the population of Baotou has not supplied tap water and the hospitalization costs of these diseases ( $\mathrm{Li}$ and Su 2003, Lu and Ling 2010, Wu et al 2011, Hu et al 2015), these studies indicates that the external costs of waste water are CNY 0.985 million for human health, CNY 3.59 billion for agriculture, CNY 3.64 billion for industry, CNY 18.63 million for life water treatment, and CNY 1.67 billion for tourism. In 2013, the total emission of industrial water is 40.15 million metric tons in Baotou, the ratio of industrial water to total waste water is 0.351 in 2009 , based on this proportion, the total waste water in Baotou is 114.4 million metric tons in 2013, indicating the total external cost of 158.836 metric tons of waste water generated arising from production of one metric ton of REO is CNY 12515.

\subsection{Damage to nature capital - radioactive substance}

Nearly all REE ores contain radioactive substance, Bayan Obo ore contains $0.032 \%$ uranium, and about 1.4 metric ton of radioactive waste slag is produced in the production of 1 metric ton of REO, thorium is about $4.27 \mathrm{~kg}$ (Xu and Peng 2009 ), its specific radioactivity is $1.74 \times 106 \mathrm{~Bq} / \mathrm{kg}$. In "Classification Criterion of Radioactive Wastes-GB91331988 ", the wastes with the specific radioactivity higher than $7.4 \times 104 \mathrm{~Bq} / \mathrm{kg}$ are radioactive waste, otherwise are non- 
radioactive waste. Therefore, the waste slag generated in the production of REO are radioactive waste, these radioactive wastes ultimately shift into the tailing slag and stored in tailing reservoir.

The report presented by the Baotou Radiation and Environmental Management Institute in 1998 showed that the total $\alpha$ activity of four waste disposal site of Bayan Obo are higher normal environmental conditions, the sample analysis of plants, animal and soil showed that the specific radioactivity in plant, animal and soil are respectively, 32, 1.18, 1.7 higher than the references. This indicating that animal, plants, and soil in Bayan Obo area have been contaminated (MEP 2009), It's impossible to state categorically the cost of radioactive waste. As stipulated in the "Administrative Regulations on Pollution Discharge Fee Levy", the charge fee for the disposal of hazardous waste does not conform national standards is CNY 1000 per metric ton. Although, and we estimate the total cost of radioactivity of production of one metric ton of REO to be CNY 1400.

\subsection{Damage to nature resources - rare earth resources}

Non-renewable natural resources used as important raw materials has its own value, decrease of these nature resources in the process of using could be recognized as a depreciation of assets, which will deprive the next generation of the usage right for this resource, therefore the extraction of non-renewable natural resources will generate an external cost. The calculation for this external cost can be based on the user cost method, and it can be calculated by equation (2), where $\mathrm{U}, \mathrm{R}, \mathrm{r}$, and $\mathrm{t}$ are respectively, represent the user cost of specific resources, the real income from resource exploitation, the discount rate, and remain life for resource exploitation ( $\mathrm{Li}$ and $\mathrm{Li}$ 2013).

$$
U=\frac{R}{(1+r)^{t}}
$$

In 2013, the operation revenue of Baotou Steel is CNY 6.08 billion, the operation cost is CNY 3.5 billion, the resource tax of REEs is CNY 0.49 billion, therefore the real income of REE production is CNY 3.01 billion. In this study, we set the discount rate to $3 \%$ as deposit rate in 2013, and the remain life of Bayan Obo mine is 25 years. Hence, we estimate the user cost of one metric ton of REO at Bayan Obo is CNY 3199 in 2013.

\subsection{Damage to ecosystem - land occupation}

Bayan Obo deposit locates in the Inner Mongolia grassland, its length is about $16 \mathrm{~km}$ and width is $3 \mathrm{~km}$, covers an area of about 48 square kilometers. Its exploitation destroys the original grassland ecosystem and bring bad effects on ecosystem service such as food production, water conservation and climate regulation, etc. therefore reduce the value of local ecosystem service, which can be recognized as the external cost of the exploitation of Bayan Obo deposit.

The service of Inner Mongolia grassland ecosystem consists of 11 types: food production, material production, water supply, gas regulation, climate regulation, clean environment, hydrological regulation, soil conservation, nutrient cycling, biodiversity, and aesthetic landscape (Xie 2015). The grassland in Inner Mongolia covers over 0.48 million square kilometers and mainly consist of three categories: desert steppe, typical steppe, and meadow steppe. Total services value in per unit of grassland ecosystem is CNY 2978030 per hectare, and 2097.71 for desert, 27110.7 for typical, and 126620 for meadow (Mu 2016). Bayan Obo lies in typical steppe, therefore we estimated that the annual external cost of land use is CNY 0.127 billion, the external cost of production of one metric ton of REO in Bayan Obo is CNY 2680 in 2013 (the production of REO in Bayan Obo is 47446 metric tons in 2013).

\section{Results and Discussion}

In this study, we measured the negative externalities (the destructive side-effects) generated in the REO production, and three methods was utilized to estimate the external cost: (1) estimating the treatment or prevention costs (including agricultural products costs, industry costs, tourism costs, tap water costs, and medical costs); (2) evaluating the service value of grassland ecosystem caused by land occupation; and (3) measuring the external cost of the depletion of REE resources. Table 1 shows the external costs of production of one metric ton of REO at Bayan Obo, the annual external costs of REO production is CNY 34739 in 2013.

Table 1. The annual external cost of production of one metric ton of REO at Bayan Obo in 2013.

\begin{tabular}{cc}
\hline Category & $\begin{array}{c}\text { External cost } \\
\text { (CNY) }\end{array}$ \\
\hline Damage to natural capital - waste water & 14945 \\
\hline Damage to natural capital - waste gas & 12515 \\
\hline $\begin{array}{c}\text { Damage to natural capital - radioactive } \\
\text { substance }\end{array}$ & 1400 \\
\hline $\begin{array}{c}\text { Damage to natural resource - rare earth } \\
\text { resources }\end{array}$ & 3199 \\
\hline $\begin{array}{c}\text { Damage to ecological system - land } \\
\text { occupation }\end{array}$ & 2680 \\
\hline \begin{tabular}{c} 
Total \\
\hline
\end{tabular} & 34739 \\
\hline
\end{tabular}

As shown in table 1, the external costs mainly come from two sources: waste water and gas. Baotou lies in northern China, and its available water is limited, the sewage discharged from the production of REO is of significant influence to water supply of local various industrial fields and ecosystem, which result in degradation of water quality and agricultural products, rising of cost in industrial and life water supply, and decreasing of tourism revenue, therefore waste water is considered as primary pollution source in the production of REO, the external costs caused by waste water discharge consist of $43 \%$ of the total external cost. In the process of REO production, coal and electricity are required in the transportation and calcination, etc. A large amount of carbon dioxide and sulfur dioxide was produced in these processes since the electricity generation primary come from coal in China, which in turn bring great negative influence to human health, the external costs of waste gas consist of $36 \%$ 
of the total external costs. However, the external costs of carbon dioxide is underestimated in this study (CNY 0.047 per ton of $\mathrm{CO}_{2}$ ), many countries levy on carbon dioxide about several tens of CNY. Land use and rare earth resource depletion consist of $16.9 \%$, and the remaining is radioactive substance. Nevertheless, in this study, since there is no other better way to evaluate the losses caused by radiation, we used sewage charges system to evaluate, which also caused the underestimating of externalities of radioactive elements. Thus, the external costs of REO production in Bayan Obo is underestimated in this study.

The REE content in Bayan Obo REO is lanthanum 25\%, cerium 50.1, praseodymium $5.1 \%$, neodymium $16.6 \%$, samarium $1.2 \%$, and other $2 \%$, the unit prices for first five individual rare earth element oxide (excluding others) are respectively, CNY 33.29, 34, 327.42, 443.21, and 28.98 per kilogram in 2013, therefore we estimate the market value (positive external cost) of 1 metric ton of REO is CNY 102661, while the negative external cost comprises of $33.8 \%$ of the market value; In 2013, the REO operation revenue of Baotou Steel Rare Earth Group is CNY 6.07 billion, the negative external cost comprises of $27.1 \%$ of the operation revenue, while the pollutant drainage fee actually paid is CNY 33.3 million, the resource tax of REEs is CNY 489.39 million, both of external costs actually paid consist of $8.6 \%$ of the operation revenue, far less than the negative external cost estimated in this study, and the internalization of the external costs would reduce the financial profit of Northern Rare Earth (Group) by 18\%.

\section{Conclusions}

Rapid increase in REO production has result in severe pollution in local environment, which also attracted much attention from academy and industry communities. However, there are currently very limited literatures to estimate the external costs of REE exploitation in China. This study aims to construct an assessment model to estimate the external costs of REE exploitation so as to provide enough information for policy making on the sustainable exploitation of REE industry.

This study constructs a framework for assessing the external costs of REE based on the LCA framework, the assessment framework is subdivided into five categories from three aspects: natural environment, human health, and natural resources. The results shown that the total external cost of production of one metric ton of REO in Bayan Obo is CNY 34739 in 2013, accounts for $33.8 \%$ of the market value, and the external costs of waste gas and water consist of $79 \%$ of the total external costs. In this assessment, some costs are underestimated, such as the effects of waste gas and the radioactive substance on agriculture and industrial products, human health, and ecosystem, as their complex behavior is so complicate that they cannot yet be fully resolved.

Although this paper mainly focuses on the total external costs of REO production, it also presents several important policy questions. First, how to lessen these externalities through effective policies. Tax and fee always the first choice, however, overweight tax could seriously restrained companies' willingness to produce and invest, as shown in this paper, the internalization of external costs of REO production in Bayan Obo would reduce the operation profit by $18 \%$. Second, how to guarantee harmed parties are adequately compensated. The externalities of REO production infringe the property interest of many groups, including normal citizen, various companies, and the ecosystem, how to compensate the harmed individual parties is a very complicating and particularity job, which would result in new external costs: transaction cost. These would imply that the government and companies should have sought for sustainable practice rather than levy on the pollution. In practice, improving mining technology to achieve zeroemission and increasing resource utilization would be effective solutions, and further analysis of the external costs and the green mining costs of REE exploitation would help to inform more detailed policy information.

\section{Acknowledgement}

We are very grateful to Zhen Zhixin and two reviewers for their critical comments on this paper.

\section{References}

Binnemans, K. and P.T. Jones, 2015. Rare earths and the balance problem. Journal of Sustainable Metallurgy, 1(1): $29-38$.

China Nonferrous Metals Industry Association, 2014. The yearbook of nonferrous metals industry of China 2014. China Nonferrous Metals Industry Association, 713p. (in Chinses)

EC JRC (European Commission - Joint Research Centre (Jrc) - Institute for Environment and Sustainability), 2010. International reference life cycle data system framework and requirements for life cycle impact assessment models and indicators, Luxembourg.

Hu, T., Y. Yu and J. Du, 2015. Research progress on economic burden of viral hepatitis patients. Zhejiang Journal of Preventive Medicine, 27(10): 1012 - 1016.

Kanazawa, Y. and M. Kamitani, 2006. Rare earth minerals and resources in the world. Journal of Alloys \& Compounds, 408-412(19): 1339 - 1343.

Li, G. and H. Li, 2013. User cost of oil and gas resources of America. Journal of Natural Resources, 28(6): 1046 1058.

Li, J., 2012. Analysis and evaluation of economical loss caused by agricultural water pollution - taking Beisu town of Zoucheng city as an example. Journal of Environmental Management College of China, 22(8): 49 -52 .

Li, J. and S. Su, 2003. Calculation model of water pollution induced economic loss for river basin. Journal of Hydraulic Engineering, 34(10): 68 - 74.

Li, X., Y. Gao, X. Kong and Z. Zhang, 2013. Health damage assessment of interior decorations based on the LCA methodology. Journal of Tsinghua University (Science and Technology), 53(1): 66 - 71. 
Lu, C. and M. Ling, 2010. Calculation of economic losses caused by water pollution in Zhengzhou city. Water Resources Protection, 26(6): $62-65+83$.

MEP (Ministry of Environmental Protection), 2009. The explanation of compiling emission standards of pollutants from rare earths industry. http://www.zhb.gov.cn/gkml/hbb/bgth/200910/t200910 22_175020.htm. (in Chinese)

$\mathrm{Mu}, \mathrm{S} ., 2016$. Spatial patterns of value of ecosystem service in temperate grassland in Inner Mongolia during 19822014. Journal of Arid Land Resource and Environment, 30(10): $76-81$.

Rollat, A., D. Guyonnet, M. Planchon and J. Tuduri, 2016. Prospective analysis of the flows of certain rare earths in Europe at the 2020 horizon. Waste Management, 49: 427 $-436$.

Stegen, K.S., 2015. Heavy rare earths, permanent magnets, and renewable energies: An imminent crisis. Energy Policy, 79: $1-8$.

Su, W.Q., 2009. Economic analysis and policy research of china's rare earth industry. China Financial \& Economic Publishing House, Beijing, p323. (in Chinese)

U.S. DOE (U.S. Department of Energy), 2010. Critical materials strategy. https://www.energy.gov/epsa/downloads/2010-criticalmaterials-strategy.
USGS (U.S. Geological Survey), 2016. Mineral Commodity Summaries Rare Earths. https://minerals.usgs.gov/minerals/pubs/commodity/rar e_earths/.

Wübbeke, J., 2013. Rare earth elements in China: Policies and narratives of reinventing an industry. Resources Policy, 38(3): 384 - 394.

Wu, H.Y., J. Li, Y.T. Li, H.M. Jin and B.K. Gu., 2011. Study on disease economic burden and intangible burdern associated with bacillary Shigellosis in Shanghai. Chinese Health Resources, 14(3): 161 - 164.

Xie, G., C. Zhang, L. Zhang, W. Chen and M. Li, 2015. Improvement of the evaluation method for ecosystem service value based on per unit area. Journal of Natural Resources, 30(8): 1243 - 1254.

$\mathrm{Xu}, \mathrm{T}$. and H. Peng, 2009. Formation cause, composition analysis and comprehensive utilization of rare earth solid wastes. Journal of Rare Earths, 27(6): 1096 - 1102.

Zaimes, G.G., B.J. Hubler, S. Wang and V. Vhanna, 2015. Environmental life cycle perspective on rare earth oxide production. Acs Sustainable Chemistry \& Engineering, 3(2): 237 - 244. 